\title{
2010s-45 \\ The Smart Border Accord and the Schengen Agreement: A Comparative Analysis of Security Policies
}

\author{
Georges A. Tanguay, Marie-Christine Therrien
}

\begin{tabular}{c}
\hline Série Scientifique \\
Scientific Series
\end{tabular}

\section{Montréal}

Octobre 2010

(C) 2010 Georges A. Tanguay, Marie-Christine Therrien. Tous droits réservés. All rights reserved. Reproduction partielle permise avec citation du document source, incluant la notice (C).

Short sections may be quoted without explicit permission, if full credit, including (C) notice, is given to the source.
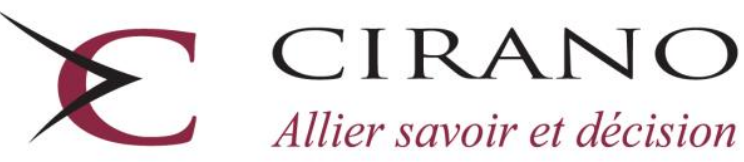

Allier savoir et décision

Centre interuniversitaire de recherche en analyse des organisations 


\section{CIRANO}

Le CIRANO est un organisme sans but lucratif constitué en vertu de la Loi des compagnies du Québec. Le financement de son infrastructure et de ses activités de recherche provient des cotisations de ses organisations-membres, d'une subvention d'infrastructure du Ministère du Développement économique et régional et de la Recherche, de même que des subventions et mandats obtenus par ses équipes de recherche.

CIRANO is a private non-profit organization incorporated under the Québec Companies Act. Its infrastructure and research activities are funded through fees paid by member organizations, an infrastructure grant from the Ministère du Développement économique et régional et de la Recherche, and grants and research mandates obtained by its research teams.

\section{Les partenaires du CIRANO}

Partenaire majeur

Ministère du Développement économique, de l'Innovation et de l'Exportation

\section{Partenaires corporatifs}

Banque de développement du Canada

Banque du Canada

Banque Laurentienne du Canada

Banque Nationale du Canada

Banque Royale du Canada

Banque Scotia

Bell Canada

BMO Groupe financier

Caisse de dépôt et placement du Québec

Fédération des caisses Desjardins du Québec

Gaz Métro

Hydro-Québec

Industrie Canada

Investissements PSP

Ministère des Finances du Québec

Power Corporation du Canada

Raymond Chabot Grant Thornton

Rio Tinto

State Street Global Advisors

Transat A.T.

Ville de Montréal

\section{Partenaires universitaires}

École Polytechnique de Montréal

HEC Montréal

McGill University

Université Concordia

Université de Montréal

Université de Sherbrooke

Université du Québec

Université du Québec à Montréal

Université Laval

Le CIRANO collabore avec de nombreux centres et chaires de recherche universitaires dont on peut consulter la liste sur son site web.

Les cahiers de la série scientifique (CS) visent à rendre accessibles des résultats de recherche effectuée au CIRANO afin de susciter échanges et commentaires. Ces cahiers sont écrits dans le style des publications scientifiques. Les idées et les opinions émises sont sous l'unique responsabilité des auteurs et ne représentent pas nécessairement les positions du CIRANO ou de ses partenaires.

This paper presents research carried out at CIRANO and aims at encouraging discussion and comment. The observations and viewpoints expressed are the sole responsibility of the authors. They do not necessarily represent positions of CIRANO or its partners. 


\title{
The Smart Border Accord and the Schengen Agreement: A Comparative Analysis of Security Policies
}

\author{
Georges A. Tanguay ${ }^{*}$, Marie-Christine Therrien ${ }^{\dagger}$
}

\begin{abstract}
Résumé / Abstract
Nous comparons les politiques de sécurité des accords de Schengen et de la frontière intelligente Canada-États-Unis en termes de coopération et de coordination. Pour ce faire, nous considérons que la sécurité nationale est un bien public dont la production doit être analysée en termes stratégiques. Nous démontrons qu'une gestion efficiente des frontières peut nécessiter que les pays participants collaborent et que les résultats de cette collaboration sont fonction de quatre facteurs fondamentaux : i) la souveraineté nationale; ii) le nombre de pays participants; iii) les problèmes de type «dilemme du prisonnier » et iv) la structure des bénéfices nationaux et le caractère public des mesures de sécurité. À la lumière de ces facteurs, nous soulignons et analysons les différences entre les accords de Schengen et de la frontière intelligente Canada-États-Unis. Nous démontrons que les États-Unis et le Canada peuvent atteindre un niveau optimal de sécurité globale en appliquant des politiques indépendantes de gestion frontalière et qu'ainsi, la mise en place d'un périmètre commun de sécurité ne serait pas nécessaire.
\end{abstract}

Mots clés : Sécurité, frontière, terrorisme, accord sur la frontière intelligente, Schengen.

Focusing on cooperation and coordination, we compare the security policies of Europe's Schengen Agreement and the Canada-U.S. Smart Border Accord. To do so, we argue that national security is a public good and its production should be analyzed in a strategic context. We show that efficient border policies could require that countries collaborate and that the outcomes of such a collaboration are function of four fundamental factors: i) national sovereignty issues; ii) the number of participating countries; iii) "prisoner's dilemma" problems and $i v)$ the payoff structure and the level of publicness related to security measures. In light of these factors, we underline the Schengen and U.S.-Canada differences. This allows us to show that the U.S. and Canada could reach optimal global security using independent border policies and a common security perimeter would not be necessary.

Keywords: Security, Border, Terrorism, Smart Border Accord, Schengen.

\footnotetext{
${ }^{*}$ Corresponding author: UQAM, ESG-DEUT, C.P 8888, Succ. Centre-ville, Montreal (Quebec), Canada, H3C 3P8. Fax: 514-987-7827; tanguay.georges@ uqam.ca.

†'École nationale d'administration publique, Montréal.
} 


\section{Introduction}

September $11^{\text {th }} 2001$ has triggered many nations into developing an acceptable balance between freedom and security by adopting or modifying different policy measures concerning border security. Members of the European Union have signed the Schengen Agreement in 1995 and continued its development and adjustments after 9/11. In 2010, 25 states are now members of the agreement. Canada and the U.S. signed the Smart Border Declaration in 2001 to increase security and secure trade. Both have sought to allow for greater freedom in mobility (goods and people) without compromising security. Even if the economic integration is at different levels between NAFTA and the EU, and that factor mobility is different in both, it is instructive to look at how both groups of countries manage their border policy. For the EU, factor mobility is defined in the terms of an economic union and a border free union is part of its objectives since its creation. It is achieved with the cooperation of all member states. For Canada and the U.S., the border is present even if it has been streamlined to help commercial exchanges through a coordination of policies. For instance, this is reflected in a survey by Goldfarb (2003) related to the development of North American Economic integration and where a question category entitled "How to secure the physical border, while facilitating trade" refers to these issues. Also, her study includes elements such as “....building on the smart-border approach,(...).(...) promote protecting entry into North America, or a "security perimeter",(...). Others suggest a Schengen-type approach in which Canadian and U.S. border guards look out for both countries' interests". Not long after the events of 9/11, public discussions were occurring in Canada on implementing a common security perimeter with the U.S. On one side, Canadian businesses were quick to approve 
of this border-free potential. On the other side, the Canadian government and the public were reacting prudently to discussions of harmonization of policies, fearing for national sovereignty (Koslowski, 2004). The Canadian government and public strongly opposed the idea of creating a common perimeter where its powerful neighbor could potentially impose its policy views. In this paper, we use the Schengen situation and public economic theory, to analyze the eventual implementation of a common security perimeter for the United States and Canada. Although there is a similar bilateral security accord between Mexico and the U.S. ${ }^{2}$, we do not include Mexico in our analysis for two reasons. First, even if some discussions have occurred at the NAFTA level on security issues, there has never been an intention to create a common security perimeter around the three countries but around the U.S. and Canada only. Second, border security remains on two bilateral agreements and therefore we consider only the U.S. and Canada in our analysis.

In the next section, we look at the basic differences between the Schengen Agreement and the Smart Border Accord in terms of coordination and cooperation for security and border issues between countries. We then identify potential strategic changes to the Smart Border Accord according to lessons learned from the Schengen Agreement. We argue that even if a supranational management of common border issues seems desirable to improve efficiency and security, the very nature of these security and border problems should be analyzed in light of current national incentives. This is the case because countries have different characteristics and goals and therefore, these "fundamentals" will lead them to take various actions. Hence, this leads us in section three to address the two basic and interrelated questions: how will the results in terms of border security be

\footnotetext{
${ }^{2}$ United States-Mexico Border Partnership Agreement signed in March 2002
} 
affected by the incentives determined by the fundamentals? What would be the results of independent national border management? To answer these questions we look at four fundamental factors that will affect security and economic outcomes: i) sovereignty issues; ii) the number of participating countries and transaction costs, iii) “prisoner's dilemma" problems and iv) the payoff structure related to different actions and the level of publicness of security measures. In section four, we apply these analytical factors to the Schengen and U.S.-Canada prevailing situations. We show that the American and Canadian fundamental factors are different than the ones for Schengen countries and that the U.S. and Canada could reach optimal global security using somehow independent border policies. The conclusion follows.

\section{Schengen: Free Mobility and Security}

\subsection{The Schengen Agreement}

The free circulation of people and goods is almost completely done in Europe as 25 members have signed the Schengen Agreement (all but three of which are members of the European Union). The lifting of border controls is first and foremost a political move towards a common territory with no border obstacles. Nonetheless, the border free union and the free mobility of factors of production answer also to economic needs. The creation of a unique space in which everyone is free to circulate is one of the objectives of European unification. But the suppression of border controls raises issues in terms of national sovereignty. It implies that the states involved, open their territory and renounce to do systematic controls on internal borders. This brings an important change to the nation state: controlled access to its territory (Tandonnet, 1998). Of the 27 member states 
of the EU, 25 have signed the Schengen Convention ${ }^{3}$; the two non signatories are

England and Ireland. Because the definition of an economic union includes the complete mobility of factor production, many of the European countries felt it was necessary to open borders in the 1980s. This is reflected in the following excerpt:

"During the 1980s, a debate opened up about the meaning of the concept of "free movement of persons ". Some Member States felt that this should apply to EU citizens only, which would involve keeping internal border checks in order to distinguish between citizens of the EU and non-EU nationals. Others argued in favor of free movement for everyone, which would mean an end to internal border checks altogether. Since the Member States found it impossible to reach an agreement, France, Germany, Belgium, Luxembourg and the Netherlands decided in 1985 to create a territory without internal borders. This became known as the "Schengen area". The name was taken from the name of the town in Luxembourg where the first agreements were signed. This intergovernmental cooperation expanded to include 13 countries in 1997, following the signing of the Treaty of Amsterdam. The Treaty of Amsterdam incorporated the decisions taken since 1985 by Schengen group members and the associated working structures into EU law on 1 May 1999." (United Nations Development Program, www.undp.md/border/Download/53.doc)

The Treaty of Amsterdam transfers the control of external borders, asylum and immigration to the members of the union. These three matters therefore do not belong to national policies and legislation at the individual level. The legislation concerning these matters is created at the level of the European parliament with implementation guidelines for the member states. The responsibility for implementation, as the control and surveillance of external borders, remain under the states' authority (Berg and Ehin, 2006, p. 59). The member states, nonetheless, remain in a situation where they need to balance national sovereignty with less control over security issues, and many other issues as a matter of fact. The Migration Policy Institute (2001) states that: “ The EU has demonstrated that when states' over-riding interest in cooperation is in fact the pursuit of

\footnotetext{
${ }^{3}$ There are actually three non-European Union countries which are part of Schengen: Norway (2001), Iceland (2001) and Switzerland (2008). The first two countries are also part of the Nordic passport union composed of Sweden, Finland, Denmark, Iceland and Norway. Three new members of the EU, Bulgaria, Cyprus and Romania have signed the agreement, but they have not yet implemented it.
} 
their national interest then cooperation is possible, but is also a laborious process of negotiation and mutual respect” (Migration Policy Institute, 2001, p.11).

According to Salter (2004), there are two ways to look at security in Europe: internal and external. The Schengen convention is based on two principles: i) internal borders may be crossed without any control and ii) in counterpart, compensatory measures are adopted such as reinforcing external border controls, a common visa policy, police and judicial collaboration, and the creation of a common information system of undesirable people (Schengen Information System or SIS). States may individually continue to do mobile and random controls close to the internal border (Tandonnet, 1998). The rules of the convention are set by the Community and lie as in a third party with a more neutral and cooperative approach: the good of the community over-rides national interests. The member states are then obliged to apply these rules as they are co-signatory of the Schengen agreement. The member states adopt measures which help implement this philosophy of balance between security and freedom. These measures are part of the European Union framework and therefore do not belong to individual nations but to the community. This is also the first example of enhanced cooperation between the member states which is now under parliamentary and judicial scrutiny. Because Schengen implies many different policy and implementation issues, the EU has gained much experience in its cooperation efforts. For instance, member states have learned to monitor each other's strategies and know how to negotiate as many opportunities present themselves for important and sensitive issues such as the establishment of the euro. Given these facts, it's clear that countries have estimated that cooperation would generate net benefits for 
them. In the next sub-section, we look at the main factors that have been used to evaluate these net benefits.

\subsubsection{Actual and Projected Benefits of Cooperation}

In order to better understand cooperation, previous studies have analyzed the Schengen agreement in regards to three main types of issues: i) the delocalization of the borders; ii) visa and iii) police force coordination. We look at these issues in turn.

\section{Delocalization of the border}

As noted above, the guiding principles of Schengen lie in a common external perimeter and compensatory measures for policy coordination. Therefore, the common external perimeter or the delocalization of the border means that border control is done away from the border and with common rules applied by each of the member states. According to Broeders (2007) and Brouwer (2008), this agreement also participates in the creation of a new digital border in Europe. The Schengen Agreement is composed of 25 members of unequal economic force, such as France, Germany or Spain who sometimes oppose the development of common policies. For instance, in March 2004, Germany, France and Britain opposed to a common special intelligence unit on the basis that they did not want to compromise intelligence gathering (International Herald Tribune, Aug.14-15, 2004). This opposition is a clear example of national sovereignty versus limit to cooperation. This limit to cooperation lies in the fact that some of the members, content with the results of the open border policy of Schengen, do not wish to develop the policy further. The members of Schengen try to achieve a delicate balance between their cooperation 
efforts and their need for individual national sovereignty. As a second example of cooperation effort, a common border guard is being discussed among members for several years. With the beginning of the implementation of the Stockholm Program in 2010, the European Commission confirmed this long-term priority (Carrera, 2010). A communication by the Commission on the feasibility of a European system of border guards (ESBG) is expected by 2014. This cooperation effort demonstrates well that if the benefits outweigh the costs to the member country, they are more likely to accept the policy. For this reason, in the common border guard project, countries with less experience or "softer" borders benefit from the experience of countries with "tighter" borders. For the more experienced countries, they benefit from having neighboring countries that let less undesirable people in, which could then trickle into their own country. The more experienced and "richer" countries also contribute to paying for the "poorer" countries of the EU.

\section{Visa issues}

The question of visa coordination is a delicate issue. Many have argued that one of the central issues in fighting terrorism was in the control of visa issuance. One of the most important tools and cornerstone of the Schengen Agreement is the SIS (Schengen Information System). This information system is common to all and is administered and updated by the EU itself. As an example, the SIS is used by embassies to access information on the demanding individuals. Even if the Single European Act includes "no provision for common immigration and asylum policies" (Niessen, 2002), the member states benefit from common information on potentially dangerous or problematic 
individuals. The benefits of cooperation on the question of visas lie mostly on economies of scale in terms of investments, time and effort, and efficiency. But it is also one of the most delicate issues as it raises the question of privacy as the information is shared by all members. The most difficult area of cooperation in the visa question is in the legal area in terms of criminal judgments and extradition processes. Since 9/11, member states have significantly enhanced their police and judicial cooperation. This increase in cooperation is seen as direct result of the increase in threat that members feel. But this increase has a negative side, as noted by Niessen (2002) "it is possible that control and deterrence will eclipse the current concerns of labor market supply and demography, leading to a more restrictionist mood". The member states might therefore feel a weakness in the EU in terms of its capacity to manage policies of security and control. This could bring back a re-nationalization of debates on immigration, and further away cooperation efforts.

\section{Police coordination}

Finally, in terms of police coordination, another example of cooperation can be given. The countries of France, Italy, Spain, Portugal and the Netherlands announced on September $16^{\text {th }} 2004$, the creation of a five country European "gendarmerie" specialized in crisis management, operational in 30 days (Cyberpresse, 09-16-04). This cooperation endeavor was initiated and is lead by France. This project is a clear example of how cooperation overrides national interests and that when the participants identify a benefit they can quickly participate in the project. This project also shows, that inside Schengen, it is sometimes easier to negotiate with a smaller number of participants who share a 
common an immediate interest, who have the money available for such a project. We can imagine that if this special police force is a success, it could be extended to other members of Schengen, just as Schengen itself which started with 5 founding members.

The events of September $11^{\text {th }}$ triggered important changes by the European Council to fight against terrorism by reinforcing police, judicial, fiscal and diplomatic cooperation (Martin, 2004). Even more reinforced since 9/11 and 3/11, police and judicial cooperation are crucial elements in Schengenland, and rely on elements of cooperation of agencies and databases. But these two last events are not the only preoccupation of the EU: questions of cost sharing will also need to be assessed as the "richer" nations contribute to help the "poorer" nations.

We have shown here the importance of cooperation for the Schengen agreement as the rules are negotiated by the member states through the community and then applied uniformly. We now look at the Smart Border Accord to explain how Canada and the U.S. manage their border policy.

\subsection{The Smart Border Accord}

Tanguay and Therrien (2004) discuss how, over the last 15 years, the U.S. and Canada have increased their coordination effort to manage the border. The culmination of this effort and following 9/11, resulted in the signing of the Smart Border Accord in December 2001. This declaration set an "official" pace to the coordination effort of both countries. Each of the 30 points of this declaration is a direct answer to specific issues 
related not only to the border itself, but also items such as visa policies, refugee/asylum claims, clearance away from the border, integrated border enforcement teams (on certain crossings), etc. As both countries remain sovereign in their policy decisions, items of the Accord represent changes/adjustments which must be made in each country individually, and are based on coordination by different implementing agencies in each country. In March 2005, the leaders of U.S.A., Canada and Mexico launched the Security and Prosperity Partnership of North American. This initiative has enabled the development of new priorities for the economy and border security. Note, however, that this initiative does not include discussions on a common security perimeter. Also, even as this initiative is done on a trilateral basis, there are only two official and operative agreements: the Smart Border Accord between the U.S. and Canada signed in 2001, and the United States-Mexico Border Partnership agreement signed in 2002.

The U.S.-Canada border has been somehow seen by Americans as a high risk since 9/11. It used to be perceived somewhat as an internal border as in Schengenland, but has, since the events, been reinforced. However, having an openness in the border while assuring security is an important challenge on the longest undefended border of the world (Cilluffo, 2001). Is Schengenland more secure than the U.S. and Canada? Is the management of their border more efficient?

In theory, the EU is more efficient because of the cooperation of police, justice and common rules, and also because of economies of scale as we mentioned above. Although, many have mentioned that this efficiency is at the cost of freedom for some citizens such 
as immigrants, asylum seekers, etc. (Tholen, 2010). The Smart Border Accord is also moving in that direction with biometric identity, or the NEXUS program. Other elements of the Smart Border Accord are similar to cooperation elements of thee Schengen Area but without a supra-national decision-making body. The Schengen Area created common standards which member countries need to achieve to keep problematic situations out. In the case of Canada and the U.S., problems are almost always managed at the border (Andreas, 2005).

Following 9/11, the U.S. government has increased security at the Canada-U.S. border. As a result, there is increased scrutiny on behalf of border agents, in some cases a slowing down of process at the actual physical border, but also a slowing down of process for "real and legal" immigrants to enter the U.S.... and by ricochet, more difficulties for terrorists to enter. An agreement such as Schengen would mean that the U.S. and Canada would need to pool their resources to redirect them to a common external perimeter with all the changes this implies. As discussed by Tanguay and Therrien (2004), this might result in some loss of sovereignty for Canada. For now, Canada and the U.S. have opted for a coordination strategy, with incremental procedures (Goldfarb, 2004), heading closely to a common perimeter without the common external border which presupposes a customs union and identical visa policies (Koslowski, 2004). An identical visa policy takes for granted also that terrorists are asking for a visa (or work permit) and that they are not nationals. The incremental procedures composed by 30 points of the Smart Border Accord vary considerably. Some points of the accord are applied only to some border crossings such as NEXUS, FAST or the IBETeams. Other 
points such as refugee/asylum processing and management, visa policy coordination and compatible immigration databases are done at the national level, between Canada and the United-States. So for now, this cooperation focuses on the screening process, but some suggest that sharing and managing of knowledge and information should be the foundation for the smart borders (Rudolph, 2008). Finally, some elements are only done by Canada (for example the permanent resident card or the biometric identifiers).

\subsection{Strategic Changes}

Major differences between the Schengen agreement and the Smart Border Accord lie evidently in the difference in economic integration. Nonetheless, both groups need to balance free movement of goods and people, and security while remaining sovereign. In the case of Schengenland, experience in negotiation, and the need to develop their economic integration has led to greater cooperation. European States have been able to achieve this balance by working together on many issues and particularly on Schengen to harmonize rules and implement security procedures. They have also made the process a rule of law by managing it through the community. Therefore, since $9 / 11$, the external perimeter of Schengen has been reinforced, and some rules on immigration and asylum have been strengthened inside but internal borders remain open.

In the case of the Smart Border Accord, the 30 points of the plan develop increased security measures which are managed at the border (even if there is clearance away from the border on certain goods, the border remains). The Canada-U.S. border is tighter since 9/11 (Ackleson, 2009). As we mentioned before, this increased security helps to keep 
terrorists from entering but also makes it more difficult for businesses to trade, transfer employees and for "normal" immigration. According to Canadian Trucking Alliance CEO, compliance with new security rules add a cost of around $\$ 500$ per truck (Today's Trucking, 2008). Also, according to some, because the large transportation companies are better able to handle new requirements than the small carriers, this will create increased specialization for cross-border trade (Hynes, 2006).

Learning from the cooperation process of Schengen and considering that Canada and the U.S. have a less developed economic integration than the EU and therefore no developed common structure such as the European Commission, the creation of an International Secretariat on Border and Security issues could be a strategic process, imitating the role of the community in the case of Schengen. Both countries have the experience with the NAFTA Secretariat, as a third party composed of members with negotiated rules. This new "Secretariat" could alleviate (at least partially) some of the sovereignty issues, until Canada and the U.S. (and possibly Mexico) pursue their economic integration into a customs union or a common market (community).

But even if a new supranational management of common border issues seems desirable to improve efficiency, the very nature of these security and border problems should be analyzed in light of current national incentives. Countries have different characteristics and goals and therefore, these "fundamentals" will lead them to take various actions. How will the results in terms of border security be affected by the incentives determined by the fundamentals? What would be the results of independent national border 
management? If coordination management is necessary to improve the public welfare of all countries within a border issue, what is the required level of coordination?

These are the questions we address in section three by looking at four fundamental factors that will affect security and economic outcomes: i) sovereignty issues; ii) the number of participants and transaction costs, iii) “prisoner's dilemma" problems and iv) the payoff structure related to different actions and the level of publicness of security measures. To do so, we analyze these factors in light of public economic theory and the prevailing situations of Canada and the U.S. on one side and the Schengen group of countries on the other side.

\section{Transnational Security and Cooperation}

\subsection{Security as a Public Good}

For any given country, blocking entry of terrorists at the border has often been seen as the best way to fight terrorism. For instance, the immediate response to 9-11 was to increase the amount of resources devoted to the security of the Canada-U.S. border. Taking an economic view, we can assume there is an efficient level of security such that the marginal cost of increased border security is equal to its marginal benefit. On the other hand, a possible obstacle in achieving this efficient level of security may come from its public nature.

First, border security can be seen as a good which is non-excludable. For example, consider the case of two countries sharing a common border. If country $A$ invests in 
border security to decrease entries by potential terrorists, this could also reduce entries by terrorists into country $B .{ }^{4}$ This fact would be especially true if an agreement such as NAFTA or Schengen facilitates border crossings between both countries. Therefore, both countries can benefit from the other country's security measures. We cannot exclude a country from benefiting (at least in parts) from the investment in border security by a neighbor country.

Second, the benefits of increased border security are in part non-rival over countries. For one, terrorism imposes costs on all people in all countries regardless of where a terrorist event occurs. Hence, if a lower number of terrorists enter one country, this should benefit a neighbor. As mentioned earlier, this is especially the case if border crossings between the two are numerous and easy. Therefore, if one country benefits from its own measures to decrease entries by potential terrorists on its territory, this does not reduce the benefits available to others.

But the public nature of border security creates problems because in order to attain a globally social optimum, all countries should base their actions on the marginal costs and benefits of all countries involved or potentially affected. If governments consider only their own "private" costs and benefits and don't take into account the marginal impact of their actions on other nations, this will improve security but they will not lead to the attainment of a social optimum. Therefore, efficient border policies may require cooperation among countries benefiting from increased border security.

\footnotetext{
${ }^{4}$ We assume only two neighboring countries in the analysis. It would be a simple task to extend the analysis to more than two countries.
} 
This cooperation can take the form of an agreement defining roles, rules and limits relative to security issues. In order to be "operational", these agreements should be somehow enforceable and individually rational so that each participant can expect gaining from them. For example, an agreement of that nature could take the form of a common security perimeter or of a coordination of immigration and trade laws, etc. Obviously, these measures would be leading to higher security while favoring trade. ${ }^{5}$

A public good requiring the participation of two or more countries is labeled as a transnational public good and in this case, the absence of a supranational authority undermines the achievement of common goods because there is no coercive force which can ensure compliance with the rules (Rhinard, 2009). If some standards and structures of international organizations can help produce these public goods, however, many factors may hinder such collaboration. We look at the main ones in the next sub-section.

\subsection{Factors Obstructing Cooperation and Coordination}

\subsubsection{Sovereignty Issues}

In a world of growing interdependence and developing economic integration, how do states remain sovereign? Is sovereignty compromised by trade agreements? How effectively can nation-states cooperate without the cost of sovereignty? In this section, we

\footnotetext{
${ }^{5}$ In light of this, the Canadian Foreign Affairs and International Trade Committee and the Canadian Council of Chief Executives have called for a North American perimeter and for a customs union between Canada and the United States (National Post, 01/23/03).
} 
first look at the definition of sovereignty. We then explain how national sovereignty is expressed differently in the European Union and in the Canada-U.S. relationship.

Political scientists have discussed the issue of national sovereignty for many years now and how it is affected by international trade agreements and relations. For instance, Bagwell and Staiger (2003) define sovereignty with different attributes. They define domestic sovereignty as the organization and effectiveness of political authority within the state, international legal sovereignty as the mutual recognition of states and interdependence sovereignty as the scope of activities over which states can effectively exercise unilateral control. With these different attributes to national sovereignty in their strictest definition, the signing of trade agreements (economic) integration has few impacts on national sovereignty. National governments need to make some changes to some of their domestic policies following trade negotiations in order to adjust. National sovereignty is not really compromised by economic integration. Some trade-offs are necessary by each nation-state in order to achieve international efficiency. But these trade-offs can be considered as more beneficial than the costs because of the gains from trade. However, further integration such as security, immigration and defense issues are policies which can affect national sovereignty.

The cooperation of states on security and immigration policies comes into conflict with the definition of interdependence sovereignty. If we look now at the Schengen Agreement in Europe, we see how the underwriting states have accepted to transfer some of their sovereignty to the Union concerning security. The participant states do not 
exercise a unilateral control of these policies on their territory. The development of the European Union as we know it today has its roots in history. "The first step in European integration was taken when six countries (Belgium, the Federal Republic of Germany, France, Italy, Luxembourg and the Netherlands) set up a common market in coal and steel. The aim, in the aftermath of the Second World War, was to secure peace between Europe's victorious and vanquished nations. It brought them together as equals, cooperating within shared institutions" (www.europa.eu.int). The creation of a common market up to the union of Europe has engaged member states in cooperative efforts to create its supra-national institutions such as the Parliament and Commission. "Its Member States have set up common institutions to which they delegate some of their sovereignty so that decisions on specific matters of joint interest can be made democratically at European level. This pooling of sovereignty is also called "European integration" (www.europa.eu.int). As we explained before, the Schengen agreement is a good example of cooperation of member states. For the benefit of accrued security, they are willing to forgo some elements of their individual sovereignty by transferring some of the policy making to the area of "Justice and Home Affairs". This also makes it almost impossible for European countries to spin out of control and enter into a conflict (world war). However, as mentioned in section 2.1.1, there are some limits to the cooperation effort in Schengen. These limits, such as having a common special intelligence unit, come to the limit of acceptable changes to national sovereignty for some of the member countries. 
In a different way from Europe, Canada and the U.S. have chosen a different path of cooperation for security policies. The signing of the Smart Border Accord acts more as a coordinating mechanism between the two countries. Interdependence sovereignty is therefore maintained in each country as they keep a complete control over their policy making. Tanguay and Therrien (2004) mention that, by not choosing a common security perimeter following the September $11^{\text {th }}$ events "both countries remain completely sovereign over their own policies and coordinate to the level they want". Even if Canada is more dependent on the U.S. at an economic level, its government and the public have clearly expressed their need to remain sovereign over their security and immigration policies. The U.S. government has not pushed further the idea of developing the common security perimeter as it also promotes its own national sovereignty.

Contrary to Europe, Canada and the U.S. have not lived through world conflicts on their own territory, nor have they been in conflict with each other (e.g. war). Therefore, they do not feel as compelled as European countries to cooperate in security issues. Because they both wish to remain sovereign and because their trade agreement does not call for increased economic integration, they feel no need to further their security cooperation into a supra-national institution which could resemble Europe's Schengen Agreement.

\subsubsection{Number of Participants ${ }^{6}$, Uncertainty and Transaction Costs}

The ratification of an agreement and obtaining its associated cooperative gains necessitates coordinated efforts among a minimal-sized group. Getting this minimum

\footnotetext{
${ }^{6}$ To generalize the discussion, we use interchangeably the terms participants and players. These can be seen as countries, states, governments etc.
} 
group to cooperate can be tricky when there are potential sources of distrust and participants must deal with the uncertain actions of others. When this is the case, achieving cooperation is a function of the players' estimation or beliefs about the others' adherence to their pledged actions. Facing this uncertainty, a critical aspect then becomes the number of participants involved in the coordination-cooperation process. All other things being equal, the number of participants involved is inversely related to a "sustainable" cooperation. The following illustrates this point. ${ }^{7}$

Consider a cooperative agreement with $N$ homogenous participants or players. Under that accord, each participant will obtain a net gain if $M$ participants respect the agreement (called the minimal-sized coalition with $M \leq N$ ). Also, assume that: i) a participant respecting the agreement gets a net gain of $G$ if the minimal-sized coalition is attained and zero otherwise; ii) a participant not respecting the agreement always obtains a net gain of g; iii) participants' probabilities of respecting the agreement are independent. Under those conditions, the decision to respect the agreement (or not) is a function of the probability that the minimal-sized coalition is reached. Naming this probability the "Minimal Probability of Adherence for Collective" (MPAC) and denoting it by $P_{R}$, a riskneutral player should respect the agreement if: ${ }^{8}$

$$
P_{R} G+\left(1-P_{R}\right)(0) \geq P_{R} g+\left(1-P_{R}\right) g
$$

From equation (1), one should respect the agreement if $P_{R} \geq \frac{g}{G}$. Therefore, basing his decision on the MPAC, the probability that one player respects the agreement is

\footnotetext{
${ }^{7}$ This illustration is based on Sandler and Sargent (1995).

${ }^{8} \mathrm{We}$ assume equality of expected gains leads to respecting the agreement. For example, respecting the agreement could have an infinitesimal advantage for political reasons.
} 
increasing in the mutual gain $G$ (if the minimal-coalition is reached) and decreasing in the gain one gets from not respecting the deal, $g$ (vice-versa). ${ }^{9}$ Also, and most importantly, the attainment of the MAPC is directly related to the number of players and the minimalsized coalition. This is illustrated in Table 1.

Table 1: Required Individual Probabilities of Cooperation

\begin{tabular}{c|ccccc}
\hline \multirow{2}{*}{ \# of Others $(M-1)$} & \multicolumn{5}{|c}{ Minimal Probability of Adherence for Collective $\left(P_{R}\right)$} \\
2 & 0.1 & 0.3 & 0.5 & 0.7 & 0.9 \\
3 & 0.3162 & 0.5477 & 0.7071 & 0.8367 & 0.9487 \\
4 & 0.4642 & 0.6694 & 0.7937 & 0.8879 & 0.9655 \\
5 & 0.5623 & 0.7401 & 0.8409 & 0.9147 & 0.9740 \\
10 & 0.6310 & 0.7860 & 0.8706 & 0.9311 & 0.9791 \\
15 & 0.7943 & 0.8866 & 0.9330 & 0.9650 & 0.9895 \\
20 & 0.8577 & 0.9229 & 0.9548 & 0.9765 & 0.9930 \\
25 & 0.8913 & 0.9416 & 0.9659 & 0.9823 & 0.9947 \\
30 & 0.9120 & 0.9530 & 0.9727 & 0.9858 & 0.9958 \\
\hline
\end{tabular}

Source: Sandler and Sargent (1995)

\footnotetext{
${ }^{9}$ Also, note that for given levels of gains, the MPAC is increasing in the players' degree of risk aversion.
} 
Knowing or estimating the gains of cooperation and the minimal-sized coalition, it's a simple task to estimate what is the individual probability of cooperation leading to the MPAC. For example, consider the case where the minimal-sized coalition is equal to 21 and the gains lead to a MPAC of 0.5 . In other words, a player will cooperate if he estimates that the joint probability that $(M-1)=20$ other players cooperate is at least $50 \%$. In order to attain just 0.5 , each other player should cooperate with a probability equal to $0.9659\left(0.9659^{20}=0.5\right)$, a very demanding condition. Two factors increase required individual probabilities of cooperation.

First, as the minimal-sized coalition increases, the required individual probabilities increase fast for a given MPAC. Second, for a given minimal-sized group, these individual probabilities increase rapidly with the MPAC. In the end, it means that the probability of cooperation required of participants is likely to be near-certain levels and therefore, even a small group may not reach a cooperative solution unless participants are pretty much certain that others will cooperate. Other than the mere "statistical" aspect of the relationship between the number of players and a minimal-sized coalition, a high number of participants may also lead to transaction costs problems.

It is well known that transaction costs usually rise as the size of a ratification group increases. These costs are not only incurred during negotiations but also throughout the duration of an agreement. Therefore, high transaction costs can impede ratification of a treaty right from the start or simply lead to future problems such as non-renegotiation of a treaty following important changes of circumstances. 
Another important factor affecting the possibility of cooperation and coordination lies in the payoff structure and the level of publicness associated with security measures. We discuss this element in the next two sub-sections.

\subsubsection{Prisoner's Dilemma}

As mentioned before, in presence of terrorist threats and because of the public nature of national security, nations should cooperate in order to attain an optimal security level. That may be the case because cooperative issues often imply a "prisoner's dilemma" aspect where it is always rational for each participant not to cooperate (or defect) even though cooperation by all would lead to the Pareto-optimal equilibrium. For example, consider the case of two countries $(A$ and $B$ ) sharing an open border and facing terrorist threats. Also, both countries estimate the other is more likely than they are to be a victim of a terrorist act. In that case, a country may under-invest because it is taking into account only its own marginal costs and benefits, and because of the increased security it expects from the other. In other words, countries are trying to free-ride by letting the other pay for increased security. This is illustrated in Table 2 where the dominant strategy for both players is to "Not Increase" its border security. ${ }^{10}$ Therefore, both players end up getting nothing while they both would have been better off cooperating using the "Increase" strategy.

\footnotetext{
${ }^{10}$ As usual in game theory analysis, the first number in each cell represents the payoff for the U.S. while the second is the payoff for Canada
} 
INCREASE

COUNTRY A

\begin{tabular}{cc|c|}
\multicolumn{1}{c}{} & \multicolumn{2}{c}{ COUNTRY B } \\
\cline { 2 - 3 } INCREASE & NOT INCREASE \\
\cline { 2 - 3 } INCREASE & 50,50 & $-40,100$ \\
\cline { 2 - 3 } & $100,-40$ & 0,0 \\
\cline { 2 - 3 }
\end{tabular}

Three things should be noted. First, ceteris paribus, a higher number of countries involved raises the potential for free-riding. Second, even in a dynamic setting (e.g.: repeated game) where players "learn" and reputations are established, the incentives to defect create uncertainty in each period and defecting may still be rational (see Dutta, 1999). Third, the incentive to free-ride is greater the more countries believe themselves to be secondary targets. We take a closer look at this aspect now.

\subsubsection{Payoff Structure and the Publicness of Security Measures}

As illustrated by the prisoner's dilemma, the incentives to cooperate or defect are embedded in the payoff structure (real or as perceived). In particular, looking at transnational security, we can note two things related to the extent of payoff asymmetry. First, it seems that the negative effects of free-riding are worst when countries are asymmetric in terms of being primary or secondary targets. Second, the likelihood of leadership by a country is greater if that nation has a lot at stake compared to others.

We can look at the role of asymmetric payoff by looking at the extent to which national security measures create private costs and benefits compared to external costs and 
benefits. In other words, what is the "underlying technology" behind the production of security? How the private and external net gains of security are produced? As we will see, potential problems differ based on the technology of public supply that applies. ${ }^{11} \mathrm{We}$ consider here two possibilities: a weakest-link technology and a joint-product technology.

\section{Weakest-Link Technology}

Consider the case of $N$ countries adopting a common security perimeter with free movements of people across member countries. In this case, we can think that terrorists wanting to attack one of the member countries will enter the perimeter through the most "lenient" country or what we will call the "weakest-link". In that case, the technology is given by

$$
G=\min \left\{g_{1}, g_{2, \ldots .} g_{N}\right\}
$$

where the smallest provision security level of the group (minimum $g_{i}$ ) determines the collective provision, $G$. An example is given in Table 3 for two nations and where each one must contribute for both to be protected (get the public benefits).

Table 3: Weakest-Link Technology

\section{COUNTRY B}

INCREASE NOT INCREASE

COUNTRY A

\begin{tabular}{c|c|c|} 
INCREASE & 50,50 & $-40,100$ \\
\cline { 2 - 3 } NOT INCREASE & $100,-40$ & 0,0 \\
\cline { 2 - 3 } & &
\end{tabular}

\footnotetext{
${ }^{11}$ The following analysis on the technology of production of public security is based on the work of Sandler et al.. For instance see Sandler and Sargent (1995), Sandler and Arce (2003a, b).
} 


\section{Joint-Product Technology}

A joint-product technology refers to the case where actions of one party (e.g. investments in border security measures) create multiple outputs that could vary in terms of their private and public components. For instance, it would be the case when one party has a "unilateral" incentive to take one action because of very large private benefits (relative to public ones). In such a case, the private benefits will raise the gains from unilateral cooperation and therefore, increase the probability of an effective collaboration. ${ }^{12}$ This is illustrated in Table 4, where Country A has very high private benefits that leads it to choose to increase border security no matter what Country B does (Increase is a dominant strategy for Country A). Given that, Country A will also choose the "Increase" strategy and therefore, the equilibrium gives the optimal global solution. We will in the next section, that this example, describes very well the U.S.-Canada situation.

Table 4: Joint-Product Technology

COUNTRY B

INCREASE NOT INCREASE

\section{COUNTRY A}

\begin{tabular}{c|c|c|}
\cline { 2 - 3 } INCREASE & 300,100 & 200,50 \\
\cline { 2 - 3 } NOT INCREASE & 100,25 & 50,80 \\
\cline { 2 - 3 } &
\end{tabular}

\footnotetext{
${ }^{12}$ As noted by Sandler and Sargent (1995), joint-product technologies could help achieving coordination actions even if this could be paradoxal since the net benefits gains from such cooperation can be relatively small if private benefits are large relative to public ones.
} 


\section{A Comparative Analysis: Schengen vs U.S.-Canada}

Last section gave a somewhat negative perspective on the possibility of attaining an optimal security zone. We showed that different countries' incentives and characteristics could impede collaboration and coordination of security policies. These impediments are even more troublesome since any potential agreement is subject to dynamic inconsistencies where countries would not respect the agreed terms due to unpredicted factors (e.g. exogenous changes). But this negative perspective could be lessened due to many factor conditions and circumstances. Two factors support our main conclusion that the U.S. and Canada could reach an optimal security using independent border policies.

First, problems related to the minimum number of participating countries (and probabilities of cooperation) could be reduced if some countries share the same beliefs and behaviors. For instance, the entire group or important sub-groups (e.g. coalitions) may simply act the same with interdependent probabilities of collaboration. Correlated probabilities of actions could be, for example, due to global public pressures and/or the possibilities of leadership by one or more countries. If this is the case, numbers in Table 1 would be lower since we had assumed independent probabilities.

Second, the payoff structure could really act as a trigger that could give countries incentives which are compatible with cooperation and coordination. As shown before, this would be the case when one country (or more), has large private interests that are in line with cooperative actions. For instance, implementing important security measures could be the dominant strategy for a country that estimates being an important target of 
terrorist attacks. Also, one country (or more) could have a lot at stake attached to the decision of cooperating. Again, the asymmetric net gains between participants along with the private and public nature of these gains could play a major role in the final outcomes.

In fact, in the end, both the payoff structure (including their private-public components) and the correlated probabilities of cooperation will be the most important factors supporting an optimal outcome, cooperative or not. To illustrate this, we now compare the situations of the Schengen group of countries with the U.S.-Canada. Table 5 gives a summary of the two cases.

Table 5: Fundamentals: U.S.-Canada vs Schengen

\begin{tabular}{|l|l|}
\hline \multicolumn{1}{|c|}{ U.S. - CANADA } & \multicolumn{1}{|c|}{ SCHENGEN } \\
\hline Number of Countries $=2$ & Number of Countries =25 \\
\hline Borders & No borders \\
\hline “Low" Transaction Costs & “High" Transaction Costs \\
\hline High Asymmetry (GDP, Target) & Low Asymmetry (GDP, Target) \\
\hline Distrust Lower Because of Borders & Distrust Higher Because of No Borders \\
\hline $\begin{array}{l}\text { Asymmetric Effects if Trade Disruption (ex. } \\
\text { CAN }\end{array}$ & No Trade Disruption \\
\hline Joint-Product Technology & Weakest-Link Technology \\
\hline
\end{tabular}


Given our discussion about treaty formation and the number of participants, comparing the Schengen Agreement and the Smart Border Accord, it seems odd at first that a common security perimeter agreement exists for a group of 25 countries and not for a group of two countries only. On the other hand, other fundamental factors presented in section three, can explain why the U.S. and Canada don't necessarily need a common perimeter in order to have an efficient security outcome. We show this in the following analysis, using some of these factors and basic game-theory.

Assume a plausible payoff matrix, shown in Table 6, where the numbers in the matrix reflect the fact that the U.S. is the main target and that Canada can be victimized based on the fact that it is a U.S. friend. The rows represent the U.S. decision to increase security or not while the columns represent Canada's decision. ${ }^{13}$ Finally, we assume that the optimal outcome is attained when both countries choose to increase their security level. For instance, we can picture this outcome as being one which would have been attained under complete collaboration associated with a common security perimeter.

Table 6: Example: U.S.-Canada Payoffs

CANADA

INCREASE NOT INCREASE

USA

INCREASE NOT INCREASE

\begin{tabular}{|c|c|}
\hline 100,80 & 80,50 \\
\hline 70,40 & 50,60 \\
\hline
\end{tabular}


First, assuming that the U.S. has important private or national gains from higher border security, the U.S. incentive is to increase border security regardless of what Canada does. ${ }^{14}$ In that case, Canada's best choice is to also increase its border security. This is based on two reasons. First, not doing so could lead the U.S. to be more cautious with human and merchandise entries from Canada. In such a case, a more stringent American border could prove costly for Canada given that more than $80 \%$ of its exports are destined for the United States. Second, a higher American border security increases the costs of conducting terrorist activities in the U.S. and this change could then shift terrorist activities to Canada. ${ }^{15}$ For these two main reasons, since the U.S. will always choose to increase its border security both countries will do so. ${ }^{16}$

This predicted outcome is based on the payoff structure and the private-public components of American border security. The possibility of an effective collaborative solution is related to the "unilateral" American incentive to take one action (e.g. increase security) because of very large private benefits ( $v s$ public ones) which raise the gains from unilateral cooperation. Moreover, that outcome is reinforced by the fact that the U.S. has a strong leadership and in terms of what could affect the North American security and trade flows.

Hence, given plausible conditions, it would then be possible to reach optimal global security using independent border policies. Given the two options in the standard

\footnotetext{
${ }^{14}$ Increasing border security is a dominant strategy for the U.S.

${ }^{15}$ For more details on that result see Sandler et al. (1983) and Im et al. (1987). Also, for a good review on substitution effects in transnational terrorism see Enders and Sandler (2003).

${ }^{16}$ This is the Nash equilibrium of this game.
} 
prisoner's dilemma setting, cooperation (increase border security for both countries) or non-cooperation (status quo), we believe it is very likely that both countries will cooperate and that therefore optimality will be reached. ${ }^{17}$

\section{Conclusion}

We outlined the basic differences between the Schengen agreement and the Smart Border Accord between Canada and the U.S. In the case of the Schengen agreement, we showed how an emphasis was created on coordination between the 25 countries, and also how rules were negotiated and applied uniformly. For the Smart Border Accord, we explained how each country implemented individually their security procedures based on the 30 points of the accord. We also considered that a strategic change to the implementation of the Accord could gain in supranational coordination. Considering that some had argued for a supranational coordinating body between the two countries, we have argued that even if a supranational management of common border issues seems desirable to improve efficiency and security, the very nature of these security and border problems should be analyzed in light of current national incentives that could lead countries into various actions. Hence, we have addressed two basic and interrelated questions: how border security results will be affected by the incentives determined by their fundamentals conditions? What would be the results of independent national border management?

\footnotetext{
${ }^{17}$ Lee mentions another possibility in which one country in effect "sells" the public good of reduced terrorism that is generated by the other country. He calls that possibility "paid-riding". We abstract from this possibility.
} 
We answered these questions in the light of four fundamental factors: i) sovereignty issues; ii) the number of participating countries and transaction costs, iii) “prisoner's dilemma" problems and iv) the payoff structure related to different actions and the level of publicness of security measures. Appling these four analytical factors to the Schengen and U.S.-Canada prevailing situations, we showed that the American and Canadian fundamental factors are different than the ones for Schengen countries and that the U.S. and Canada could reach optimal global security using somehow independent border policies.

This possibility is based on the fact that the U.S. has important national gains from higher border security and therefore, the U.S. incentive is to increase border security regardless of what Canada does. This should also lead Canada to increase its border security for two reasons. First, not doing so could lead the U.S. to be more cautious with people or merchandise entries from Canada. This more stringent American border could prove costly for Canada given that more than $80 \%$ of its exports are destined for the United States. Second, a higher American border security could shift terrorist activities to Canada. Therefore, given these incentives it would be possible to reach optimal global security using somehow independent border policies and a common security perimeter would not be necessary.

The point is not that collaboration, taking the form of a common security perimeter or more common immigration rules, doesn't allow attaining optimal security. Rather, we should analyze and decide if the costs of losing independent policy-making (sovereignty 
over trade, immigration, security etc.), because of the adoption of a common security perimeter, are justified since we may well reach an optimal security level given the incentives we have described. Finally, note that from a managerial perspective, in all cases, the creation of a supranational body taking the form of an International Secretariat could help in coordinating security policies. The implementation of such a body could help alleviate sovereignty issues between the two countries. 


\section{REFERENCES}

Ackleson, J. (2010). "From "Thin" to "Thick" (and Back Again?): The Politics and Policies of the Contemporary US-Canada Border", American Review of Canadian Studies, Vol. 39, No. 4, p. 336-351.

Andreas, P. (2005). "The Mexicanisation of the U.S.-Canada Border: Asymmetric Interdependence in a Changing Security Context", International Journal, Vol. 60, No. 2 (Spring 2005), pp. 449-462.

Bagwell, K. and R. W. Staiger (2003). National Sovereignty in an Interdependent World. Paper online from K. Bagwell, Department of Economics, Columbia University.

Berg, E. and P. Ehin (2006). "What Kind of Border Regime is in the Making?: Towards a Differentiated and Uneven Border Strategy", Cooperation and Conflict, vol. 41, p. 53-71.

Broeders, D. (2007). "The New Digital Borders of Europe: EU Databases and the Surveillance of Irregular Migrants”, International Sociology, vol. 22, p. 71-92.

Brouwer, E. R. (2008). Digital Borders and Real Rights Effective Remedies for ThirdCountry Nationals in the Schengen Information System, Leiden Boston Martinus Nijhoff Publishers.

Carrera, S. (2010). "Towards a Common European Border Service? ", Center for European Policy Studies, Working Document, No. 331, June, 39 pages.

Dutta, P.K. (1999). Strategies and Games: Theory and Practice, MIT Press, 476 pages.

Enders, W. and T. Sandler (2004). "What Do We Know about the Substitution Effect in Transnational Terrorism?”, in A. Silke (Ed.), Researching Terrorism: Trends, Achievements and Failures, Frank Cass, Ilford, p. 119-137.

Fife, R. and A. Dawson, (2003). Manley Rejects Dismantling Border. National Post, January 23, 2003, p. A4.

Flynn, S. (2002). "Transforming Border Management in the Post-September 11 World", Governance and Public Security, Campbell Public Affairs Institute, Maxwell School of Citizenship and Public Affairs, Syracuse University, p. 37-51.

Goldfarb, D. (2003). "Beyond Labels: Comparing Proposals for Closer Canada-U.S. Economic Relations", C.D. Howe Institute Backgrounder, The Border Papers Series, vol. 76, October, Canada.

Goldfarb, D. (2004). "Risky Business: U.S. Border Security and the Threat to Canadian Exports", C.D. Howe Institute Commentary, The Border Papers Series, n ${ }^{\circ}$ 177, March 2003. 
Golob, S. R. (2002). "North America Beyond NAFTA? Sovereignty, Identity, and Security in Canada-U.S. Relation", Canadian-American Public Policy, vol. 52, December, p. 1-44.

Hynes, J. (2006). “Building a Smarter Border”, Canadian Sailings, July $3^{\text {rd }}$, p. 14-15.

Im, E. I., J. Cauley and T. Sandler (1987). "Cycles and Substitutions in Terrorist Activities: A Spectral Approach”, Kyklos, vol. 2, n 40, p. 223-255.

International Herald Tribune (2004). EU's chief of security pushes for border unit. Saturday-Sunday, August 14-15, 2004, p. 3.

Koslowski, R. (2004). International Cooperation to Create Smart Borders, Paper prepared for the conference on North American Integration: Migration, Trade and Security, organized by the Institute for Research on Public Policy (IRPP) in collaboration with the John Goodwin Tower Center for Political Studies at Southern Methodist University, Fairmont Chateau Laurier, Ottawa April 1-2, 2004.

Lee, D. R. (1988). "Free Riding and Paid Riding in the Fight Against Terrorism", American Economic Review, vol. 78, n 2, p. 22-26.

Macklin, A. (2002). Borderline Security. Public Law and Legal Theory Research Paper $\mathrm{n}^{\circ}$ 02-03, University of Toronto, Faculty of Law.

Martin, F. A. (2004). "The European Union and its Fight Against Terrorism", Working Paper Analysis Del Real Instituto, Real Instituto Elcano, Spain.

Migration Policy Institute, Immigration and National Security, Background Paper, September 28, 2001, Washington DC, USA.

Rhinard, M. (2009). "European Cooperation on Future Crises: Toward a Public Good?". Review of Policy Research, Vol. 26, No. 4, p. 439-455.

Rudolph, C. (2008). “Creating Smart Borders”, Fraser Forum, p. 9-10.

Salter, M. B. (2004). "Passports, Mobility and Security: How Smart Can the Border Be?", International Studies Perspectives, n 5, p. 71-91. 
Sandler, T., J. Tschirhart and J. Cauley (1983). "A Theoretical Analysis of Transnational Terrorism", American Political Science Review, March 1983, p. 36-54.

Sandler, T. and Arce M. D.G. (2003a). “Terrorism and Game Theory”, Simulation and Gaming, vol. 34, n 3, p. 319-337.

Sandler, T. and Arce M. D.G. (2003b). "Pure Public Goods versus Commons: BenefitCost Duality”, Land Economics, vol. 79, n 3, p. 355-368.

Tandonnet, M. (1998). «Libre circulation et sécurité en Europe », Défense nationale, vol. 54, Juillet 1998, p. 120-130.

Tanguay, G.A. et Therrien, M-C. (2004). "Protecting Canada and the U.S. against Terrorism: a Common Security Perimeter?" in Alan M. Rugman (Ed) North American Economic and Financial Integration: Research in Global Strategic Management, Volume 10. Oxford: Elsevier, p. 85-96.

Tholen, B. (2010). "The Changing Border: Developments and Risks in Border Control Management of Western Countries", International Review of Administrative Sciences, vol. 76, p. 259-278.

Today's Trucking (2008). "Smart Border Accord Needs to be Restored: Bradley", Today's Trucking. April 23. Cleveland, Ohio. 